\begin{tabular}{|l|c|c|c|}
\hline Jus et civitas & $\begin{array}{c}\text { Vol. VIII(LXII) } \\
\text { No. } 1 / 2021\end{array}$ & $1-8$ & $\begin{array}{c}\text { A Journal of Social and Legal } \\
\text { Studies }\end{array}$ \\
\hline
\end{tabular}

\title{
TEACHERS PROFESSIONAL SATISFACTION AND SOLIDARITY IN A CHANGING SCHOOL ORGANIZATION
}

\author{
Simona Eftimie, Alina Mărgărițoiu \\ Petroleum - Gas University of Ploiesti, Bd. Bucharest, no. 39, Ploiesti, Romania \\ e-mail: simone_eftimie@yahoo.com \\ DOI:10.51865/JETC.1.01
}

\begin{abstract}
In the context of social challenges, of school organization continuous change and teachers looking for their professional identity, we propose to identify which are the reasons that teachers continue to perform this profession, what they like and dislike about their job / professional environment. So, this paper aims to analyse some issues concerning professional values associated with their satisfaction for their job and professional solidarity of teachers from pre-university level. For this purpose, we have proposed a qualitative study, based on check - list (Sort Card) and interview. We have used check list (sort cart as instrument) in order to establish a hierarchy of the reasons that teachers (investigated subjects) like and what they dislike about their job; and also, we have used interview in order to complete the information about our subjects' professional satisfaction. Other results are discussed here.
\end{abstract}

Keywords: teacher; profession(al); change; satisfaction; solidarity.

\section{Change and solidarity in school organization. Conceptual delimitations}

School organization is challenged today by the continuous wave of changes (and pressures) of external factors: science, technology, economy, politics, culture, society. And this phenomenon is produced in the context that school become lately - more obvious than ever - an open organization.

Didactic profession is looking for its identity ${ }^{1}$. And this searching process is developing simultaneously with the process of social, economic, cultural, technological changes. The organizations are influenced by these changes, and also school organization is affected.

Researchers have demonstrated interest for this issue of professional identity of teachers and a finding was that "while teacher education research in primary and secondary education levels has reported that professional identity is a key driver which could

\footnotetext{
${ }^{1}$ Emil Păun, Pedagogie. Provocări şi dileme privind școala și profesia didactică, Editura Polirom, Iași, 2017, p. 161.
} 
affect how primary and secondary teachers teach, how they develop professionally and how they approach educational changes (Cardelle-Elawar, Irwin \& Sanz de Acedo Lizarraga, 2007; Cheung, 2008; Day, 2002; Young \& Erickson, 2011), comparatively, there is limited empirical evidence to understand post-secondary teachers' professional identity and how it might affect their motivation towards their work roles".2

An important issue concerning the profession identity construction for teachers emphasizes Professor Emil Păun ${ }^{3}$ that focus our attention on the dynamics of professionalization of didactic career: the approach of pedagogy through finalities generated a teacher - expert which training is based excessively on standards and norms; but reflexivity (and the reflexive practice) is also important for current decisions of teachers during their activity.

Permanent changes and challenges in school and society request a reflexive practice for teachers - they are challenged to develop their abilities for research so that, beyond their ordinary duties (to study curricula, to project, implement and evaluate curricula, to manage classroom activities, to manage his / her own career etc.), to be able to identify difficulties of didactic process, then the factors that produce these difficulties and also find (and experiment) better ways to limit / eliminate the problems. Their mission is not an easy one. So, more than never they have to learn to act like a team.

Organization change is a process that involves two important conditions ${ }^{4}$ : the awareness about the need for change and the involvement in the process of changing. Working groups could be more productive than individuals. The group develops important collective values (like cooperation, belonging etc.), motivate the members and offer them security.

Petru Vîrgă (2008) indicated that managers of change should be aware about the fact that people do not react only individual to the change, but organizational changes also determine collective reactions. Organization climate influence the involvement of employees, a supportive climate being characterised by harmony, friendship, cooperation, sociability, personal freedom. Also work satisfaction is correlated with teamwork and employees' perception on involvement and personal signification of involvement are important for organization change ${ }^{5}$.

Professional satisfaction is considered an attitudinal variable that reflects what people generally feel about their work and in particular about some specific aspects and it is measured by questioning people about their work (a multi-factorial approach proposed by different studies: work, accomplishments, salary, promoting, professional

\footnotetext{
${ }^{2}$ Lee Ai Noi, David Kwok, Karen Goh, Assessing Teachers' Professional Identity in a Postsecondary Institution in Singapore, The Online Journal of New Horizons in Education - October 2016 Volume 6, Issue 4, p. 38, https://www.tojned.net/journals/tojned/articles/v06i04/v06i04-04.pdf, accessed in May 2021.

${ }^{3}$ Emil Păun, Pedagogie. Provocări și dileme privind școala și profesia didactică, Editura Polirom, Iași, 2017, p. 143.

4 Petru Vîrgă, Solidaritatea în organizații. În: Eugen Avram, Cary Cooper (coord.), Psihologie organizațional - managerială. Tendințe actuale, Editura Polirom, Iași, 2008, p. 425, 426.

5 Petru Vîrgă, Solidaritatea în organizații. În: Eugen Avram, Cary Cooper (coord.), Psihologie organizațional - managerială. Tendințe actuale, Editura Polirom, Iași, 2008, pp. 421-422.
} 
development, control, colleagues / interpersonal relationships, communication, recognition etc.). ${ }^{6}$

\section{Research Methodology}

Purpose of Study

In this context that school organization is changing and teachers are looking for their identity, our (dominant qualitative) study proposes for reflexion and analyse some issues concerning work satisfaction and professional values with focus on professional solidarity of teachers from pre-university level:

Objective 1: to establish a hierarchy of professional values, as indicators for work satisfaction from investigated teachers' perspective, starting from what they like and dislike about their job environment;

Objective 2: to identify the perspective of our subjects on professional solidarity concretised in altruistic behaviours and helping in needs colleagues and schools / students.

\section{Participants, procedure and methods}

Our study has been conceived as a qualitative one, our main focus being the discussion about the change of perspective of teachers during challenging times considering their professional values and their professional interactions (teacher - teacher, teacher mentor, teacher - staff managers etc.).

A limit of our study was that our sample was not a representative one, but a spontaneous group of teachers from pre-university level. The subjects involved in our study were 19 teachers from pre-university level, all women, aged between 24 and 59 years old, with various field expertise and experience in teaching, which are living and working both in urban and rural area. We have to mention that, considering the exclusive representation of feminine gender, another limit of our study is the absence of male perspective considering the issues approached.

For our study purpose we have started from a reflexive exercise considering values that indicate professional satisfaction for investigated teachers. We have used card sorting as instrument meant to identify what teachers (investigated subjects) like and what they dislike about their job and also focus group interview in order to complete the information about our subjects' professional satisfaction.

The inspiration for using card sorting was an exercise that we have proposed during a program for continuous training of teachers; card sort is an instrument used a lot in career counselling. Considering the satisfaction of our subjects for their working

\footnotetext{
${ }^{6}$ Daniela Vercellino, Satisfacția profesională - teorii și instrumente de măsură. În: Eugen Avram, Cary Cooper (coord.), Psihologie organizațional - managerială. Tendințe actuale, Editura Polirom, Iași, 2008, pp. 520-544.
} 
environment, the professional values (that we have considered as a reflection of their professional satisfaction) verified are described in the table below:

VALUES

\begin{tabular}{l|l}
\hline- Recognition, & - Achievement \\
\hline- Leadership, & - Helping \\
\hline- Money, & - Independence \\
\hline- Creativity, & - Variety \\
\hline- Teamwork & \\
\hline
\end{tabular}

Table 1. Values important for professional environment - research variables

\section{Data analysis and interpretation}

Considering the objectives of our study, here are some of the main results about professional values and work satisfaction from teachers (subjects of our study) obtained by card sort exercise and completed by discussions with teachers during focus - group interviews:

a) The factors/values indicated as satisfactory for their working place.

The hierarchy established from data analysis is presented in the table below:

\begin{tabular}{c|c}
$\boldsymbol{R A N K}$ & $\boldsymbol{V A L U E S}$ \\
\hline$I$ & - Teamwork \\
\hline$I I$ & - Helping \\
\hline$I I I$ & - Achievement \\
\hline$I V$ & - Recognition \\
\hline$V$ & - Gamble (as predisposition for risk) \\
\hline
\end{tabular}

Table 2. The hierarchy of values - indicators for a satisfactory work environment

Teamwork has obtained the highest score from our subjects. So, teachers seem to like working as a team and a reason for it is that "working in groups makes the job easier" and "I do better any job when I do with some one's help". We consider that this is an important issue for these days of teaching profession when it is important to be reflexive, to recognize your limits (for example, about your digital abilities) and ask for help.

Helping obtained the second score in the issue of "I like about my job". This result indicates that not only asking for help but offering personal help (for other people, colleagues etc.) is important for our teachers. They are enjoying offering their help, especially to their new / debutants colleagues or to help succeed a colleague that has made a mistake. It is not something new that didactic profession, as other social professions, involve altruistic, supportive behaviours.

Achievement is on the third place as importance for our subjects. For teachers, challenges are important (although less important than working as a team and helping), so that we could consider that it is an important characteristic for this profession (for the professionalization / identity of the didactic career) due to the responsibility that this job 
is associated with (the social characteristics of education finalities). Our subjects have declared that they are open to learn something new in every task, to do the best, to find opportunities to enrich their job.

Recognition seems to be important although not the most important for teachers; it is important for social image and their professional identity to be respected by others and by community. And still teamwork, helping and achievement remain in top, which confirm the importance of altruistic behaviours for teachers (they are able to post-pone the satisfaction for their personal needs and be in service for others).

And, as a complementary value for achievement, gamble/taking risks complete the image for a professional disposed to learn from mistakes, to accept challenges taking risks in order to progress. This is an important issue for a reflexive teacher with abilities for research, as we have mentioned before.

b) The factors/ values indicated as unsatisfactory for their working place.

The hierarchy established from data analysis is presented in the table below:

\begin{tabular}{c|l}
$\boldsymbol{R A N K}$ & \multicolumn{1}{|l}{ VALUES } \\
\hline$I$ & - Money \\
\hline$I I$ & - Variety \\
\hline$I I I$ & - Leadership \\
\hline$I V$ & - Independence \\
\hline$V$ & - Creativity \\
\hline
\end{tabular}

Table 3. The hierarchy of values - indicators for an unsatisfactory work environment

Considering the factors / conditions unsatisfactory for our subjects, the highest score was for money. This is an old issue for the didactic profession in Romania; the low level of the salaries (although lately the situation improved in a sense) could be an indicator for the social recognition of this profession. Our teachers declared that they find other kind of rewards (besides money that could by modern / new things for themselves and their families) like gratitude of the children and their families, the joy of new achievement (personal knowledge and abilities or pupils' achievements) and helping, working as a team etc.

In a world of rapid and permanent changes, is not a surprise for us to discover that our teachers to indicate the importance of stability and routines and their disapproval for variety. Teachers need time to practice, as well as children; working with people, the time for practicing and learning from mistakes in order to see long term effects in pupils' behaviour is important. Many new tasks, working with different people, changing the job / the job environment and especially when the change produces too often, this could lead to anarchy in the system.

An interesting choice of our subjects was their disapproval for leadership which could lead us to a connection with their need for recognition. Our study subjects do not have managerial positions, and in their classrooms good teachers lead didactic process but from shadow and let the pupils enjoying their freedom to choose, to negotiate the plans 
etc. So, this democratic behaviour of teachers could be a good opportunity for pupils to come to the conclusion / to recognize the authority of their teachers as a leader, looking for help and in the same time having the freedom to choose and to manifest initiatives.

As a confirmation for teachers' disapproval for variety and their preference for team working, they also mentioned that do not like independence, attitude manifested as: accepting orders from superiors, using determined directions and routines that gave stability and continuity to the didactic process. From the discussions with our subjects, their dislike for independence should not be seen as not taking risks but maintaining the dynamic equilibrium between change and stability in educative process.

And, again, their disapproval for creativity could be seen as proves for professionalism, because experimentation without discernment could be dangerous because of uncontrollable effects on pupils. So, a responsible behaviour of a professional teacher involves more prudence than other fields because sometimes the consequences on children could be irreversible / difficult to fix.

And the future will prove what kind of effects will determine all these experiments due to the context of pandemic situation on young people and future society.

Objective 2 was to identify the perspective on professional solidarity concretised in altruistic behaviours and helping in needs colleagues and schools / students.

As we have discovered in a previous $\operatorname{study}^{7}$, teachers / parents (and teachers as parents) have mentioned routines changes and difficulties considering school activities, communication channels, possessing and using technology for communication during online classes.

This context, as our subjects indicated, was an opportunity for altruistic / pro-social behaviours (as we have also found in a previous study ${ }^{8}$ ) and professional solidarity concretised in behaviours like:

- Trainings for teachers leaded by other teachers from their schools, specialists in Informatics (in order to initiate / develop their digital abilities);

- Developing forums (with open access or with limited access - only for identified teachers from different schools) where everybody could post links about trainings / webinars / tutorials about using distance communication and distance teaching;

- Mentoring teachers or pupils / students / parents with poor digital abilities (often they are using social networking - Facebook or WhatsApp, for example - and find difficult to write a text using Microsoft Word);

- Managers have offered support in every way to colleagues, parents, students considering communication technology (not only software but also finding sponsors / developing projects for obtaining the devices that facilitate distance communication).

\footnotetext{
${ }^{7}$ Simona Eftimie, A Healthy Family Model During Pandemic Times, Jus et Civitas, vol VII (LXXI), no 1/2020, pp. 57.

${ }^{8}$ Simona Eftimie, A Healthy Family Model During Pandemic Times, Jus et Civitas, vol VII (LXXI), no 1/2020, pp. 62 .
} 


\section{Research conclusions}

It is important to mention that the purpose of our card sort exercise was to identify what teachers appreciate about their work (what they consider important / satisfactory for their work).

But it is also important to find which of these values are satisfied; because when we find an obvious disequilibrium between what they value (ideal) and what they find as satisfactory about their work (reality), this situation could lead to professional dissatisfaction - this is an intention for future direction of our studies.

The results of our study lead to the conclusion that teachers valorise more in their work and in their environment team working and helping behaviours rather than social recognition, money, leadership or independence.

Solidarity could be seen as the opposite to egoism. Egoism could be the sign for education system pathology. We are a competitive society and this transforms us in sick persons, affecting the main purpose of education: our humanity. Teaching profession has a social character; from every angle we are analysing the problem, we got to the conclusion that everything could be done through team effort (teachers and pupils, teachers working together, teachers and parents, teachers and other specialists etc.).

And we believe that these conclusions are important especially for those that are willing to choose their career - to be reflexive and decide if they are disposed to make these kinds of compromise: to obey, to be leaded, to have less money and less social recognition, but to fulfil through their pupils, to be part of / work as a team and seen in consequence and not necessarily as an individual, to assume your team (profession) successes and also its failures, to learn continuously, not to have certitudes (generally available solutions) and being criticized about that etc.

Also, it is important for society and political responsible that not always creativity and innovation and uncontrollable changes are the answers for a good education but also routines and perseveration, and the patience to see results are important for our children becoming.So, we agree to the theory of James Clear about developing new healthy habits that could help us to produce a change and lead us to success:

"If you want to master a habit, the key is to start with repetition, not perfection, you need to practice. You don't need to map out every feature of a new habit. You just need to practice it.",9

In all these findings we could find the difficulty and also the beauty of teaching profession, the paradox / challenge of combining change and routine, teamwork and taking risks, the need for recognition and the preference for being leaded.

\footnotetext{
9 James Clear, Atomic Habits: An Easy \& Proven Way to Build Good habits \& Break Bad Ones. Tiny Changes, Remarkable Results, Avery an imprint of Penguin Random House, New York, 2018, p. 117.
} 


\section{Bibliography}

1. Ai Noi, Lee, Kwok, David, Goh, Karen, Assessing Teachers' Professional Identity in a Postsecondary Institution in Singapore, The Online Journal of New Horizons in Education - October 2016, Volume 6, Issue 4, pp. 38-51, https://www.tojned.net/journals/tojned/articles/v06i04/v06i04-04.pdf, accessed in May 2021.

2. Eftimie, Simona, A Healthy Family Model During Pandemic Times, Jus et Civitas, vol VII (LXXI), no 1/2020, pp. 55-64.

3. Clear, James, Atomic Habits: An Easy \& Proven Way to Build Good habits \& Break Bad Ones. Tiny Changes, Remarkable Results, Avery an imprint of Penguin Random House, New York, 2018.

4. Păun, Emil, Pedagogie. Provocări și dileme privind școala și profesia didactică, Editura Polirom, Iași, 2017.

5. Vercellino, Daniela, Satisfacția profesională - teorii și instrumente de măsură. În: Eugen Avram, Cary Cooper (coord.), Psihologie organizațional - managerială. Tendințe actuale, Editura Polirom, Iași, 2008, pp. 520-544.

6. Vîrgă, Petru, Solidaritatea în organizaţii. În: Eugen Avram, Cary Cooper (coord.), Psihologie organizațional - managerială. Tendințe actuale, Editura Polirom, Iași, 2008, pp. 407 - 429.

\section{Satisfacția profesională și solidaritatea profesorilor într-o organizație școlară în schimbare}

\section{Rezumat}

În contextul provocărilor sociale, a unei organizații școlare în schimbare și a unor profesori în căutarea identității profesionale, ne întrebăm care sunt motivele pentru care profesorii continuă să practice această profesie, ce le place şi ce le displace în legătură cu profesia/locul lor de muncă. Astfel, acest articol îşi propune să analizeze câteva aspecte legate de valorile profesionale asociate cu satisfacția lor pentru locul de muncă și solidaritatea profesională a profesorilor din învățământul preuniversitar. In acest scop, ne-am propus un studiu calitativ bazat pe check-list (card sort) și interviu. Am utilizat checklist pentru a stabili o ierarhie a motivelor pentru care profesorilor investigați le place sau nu locul lor de muncă. De asemenea, am utilizat interviul pentru a completa informațiile despre satisfacția lor profesională. Alte rezultate sunt de asemenea discutate aici. 